\title{
Exploring the determinants and outcomes of intimate partner violence during pregnancy for Guyanese women: Results from a nationally representative cross-sectional household survey
}

\author{
Lior Miller $^{1}$ and Manuel Contreras-Urbina ${ }^{2}$
}

Suggested citation Miller L, Contreras-Urbina M. Exploring the determinants and outcomes of intimate partner violence during pregnancy for Guyanese women: results from a nationally representative cross-sectional household survey. Rev Panam Salud Publica. 2021;45:e6. https://doi.org/10.26633/RPSP.2021.6

\section{ABSTRACT}

\begin{abstract}
Objective. To determine predictors associated with physical violence during pregnancy, and to determine the relationship between exposure to intimate partner violence during pregnancy and women's health and suicide ideation in Guyana.

Methods. A secondary data analysis of a cross-sectional household survey. Multivariate logistic regression models were fitted to the data to estimate the association between physical violence during pregnancy, controlling partner behavior, and other predictors. Ordered logistic regression models were fitted to estimate the association between physical violence during pregnancy and women's health, and lifetime physical partner violence and overall health. Logistic regression models were fitted to estimate associations between physical violence during pregnancy and lifetime physical partner violence and overall health and suicide ideation.

Results. The prevalence of lifetime physical/sexual intimate partner violence was 38.8\%, current physical/ sexual intimate partner violence $11.1 \%$, and violence during pregnancy $9.2 \%$. Controlling partner behavior was significantly and positively associated with maternal experience of physical violence during pregnancy. Experiencing physical partner violence during pregnancy, but not lifetime physical partner violence, was associated with significantly increased odds of poor overall health. Physical violence during pregnancy and lifetime physical violence were both significantly associated with increased odds of suicide ideation.

Conclusions. The prevalence of violence during pregnancy in Guyana is high and is associated with adverse health outcomes. These findings suggest the need for intimate partner violence prevention, and for integrating intimate partner violence screening and treatment into antenatal care, reproductive health services, and maternal and child health programs and services to identify and treat at-risk women.
\end{abstract}

Keywords Intimate partner violence; pregnancy; domestic violence; physical abuse; mental health; Guyana.

Intimate partner violence (IPV) is a significant public health and human rights concern globally, yet limited research has explored the determinants and health outcomes of IPV for pregnant women, particularly in Latin American and the Caribbean
(LAC) (1). IPV includes physical and sexual violence, emotional violence, and controlling behavior (2).

In LAC, lifetime IPV prevalence (defined as reported ever experienced sexual or physical violence by an intimate partner)

\footnotetext{
1 George Washington University, Washington, D.C., United States of America. $\bowtie$ Lior Miller, liormiller@gwu.edu
} 
ranges from $17 \%$ in the Dominican Republic to $53.3 \%$ in Bolivia, while IPV within the last 12 months (also referred to as current IPV) ranges from $7.7 \%$ in Jamaica to $25.5 \%$ in Bolivia, with most Demographic and Health Surveys and Reproductive Health Surveys finding that $25 \%$ to over $50 \%$ of women reported lifetime IPV (1). The median lifetime IPV prevalence was $24.5 \%$ and the median IPV prevalence in the last 12 months was $13.05 \%$. In Guyana, where the current study took place, previous data on IPV in Guyana are scarce; one recent study of patients presenting with traumatic injuries to a Guyanese emergency department found a self-reported IPV prevalence of $16 \%$ (3). However, these data were not based on a nationally representative sample, and used a single question to screen for IPV, which likely lowered sensitivity and led to an underestimate of the true prevalence (3). The current nationally representative survey on which this secondary analysis is based estimates that $38 \%$ of survey respondents experienced physical and/or sexual violence in their lifetime, and $11.1 \%$ experienced current (in the last 12 months) physical and/or sexual violence (4), which are above the median for the LAC region.

Attention to IPV during pregnancy (IPV-P) has increased due to the substantial health consequences for women and children and high prevalence $(5,6)$. IPV-P may cause injury to the mother and the fetus due to direct trauma; adverse maternal health behaviors such as delayed and/or reduced antenatal care, reduced skilled delivery care, and increased smoking during pregnancy $(5,7)$; negative reproductive health outcomes including miscarriage, premature rupture of membranes; preterm delivery, unsafe abortion, low birthweight, and perinatal death $(5,8,9)$; increased risk of child abuse and neglect in the postnatal period (10); and other physical and mental health outcomes including physical impairment and depression $(5,11)$ as well as suicide ideation (12) and suicide attempt (13). A systematic review of the mental health sequelae of IPV-P in low- and middle-income countries found that it increased the odds of antenatal depression by 1.69-3.76 and the odds of postnatal depression by 1.46-7.04, with suicide ideation rates during pregnancy ranging from $5 \%$ to $11 \%$ and during postpartum $2 \%$ to $22 \%$ (14). IPV-P is also associated with intrauterine growth retardation and interferes with attachment and bonding in the postpartum period as well as breastfeeding (5). In addition to the risks posed by IPV during pregnancy, IPV before pregnancy, including child abuse, is associated with preterm birth and low birthweight (15).

The available data suggest that IPV-P has a higher prevalence than other conditions commonly screened for in antenatal care (6) such as pregnancy-induced hypertension, which affects an estimated $10 \%$ of pregnancies globally (16). A 2005 World Health Organization (WHO) multi-country study, which used population-based surveys, found that IPV-P ranged from 1\% in Japan to $28 \%$ in Peru (17). A more recent systematic review found IPV-P prevalence ranging from $3 \%$ to $44 \%$, varying by setting and type of violence, with sexual violence associated with the lowest prevalence and emotional/psychological violence with the highest prevalence. While the consequences of IPV during pregnancy are clear, the body of literature on risk factors associated with violence during pregnancy is less developed, particularly outside of North American and European settings (18). There is also a lack of recent representative population-based studies, as much of the literature uses case series or clinic/hospital-based populations with small sample sizes and diverse definitions and methods. Known risk factors associated with violence during pregnancy include younger age (19), having an unwanted or unplanned pregnancy (20), partner's alcohol use, lower maternal education, and maternal experience of family violence during childhood (6). There is also evidence that controlling partner behavior or coercive control, marked by a pattern of control, isolation, violence, and intimidation (21), is significantly associated with $\operatorname{IPV}-\mathrm{P}(22,23)$, and is predictive of higher levels and more serious types of IPV (24).

Guyana is a middle-income country on the northern coast of South America with strong economic and cultural ties to the Caribbean and a population of 748000 (25). Since 2012, universal screening for IPV/sexual assault and sexually transmitted infections has been instituted (26). The legislative framework to address IPV in Guyana includes the Domestic Violence Act in 1996, the Sexual Offences Act of 2010 which criminalized marital rape (4), and the National Policy on Domestic Violence (27). The Guyana Police Service has also instituted a zero-tolerance policy for domestic violence (4). However, the limited data on IPV-P limit the effective development, implementation, and evaluation of national strategies and policies and advocacy efforts (4).

The objectives of this study are to (1) determine the predictors associated with experiencing physical violence during pregnancy and lifetime physical violence and (2) determine the relationship between exposure to physical violence during pregnancy and women's health and self-harm behaviors using data from a 2017 nationally representative household survey of women in Guyana. The ecological model of violence against women was the conceptual model used to drive the research hypotheses, selection of predictors, and analysis (28). The hypothesis for the first research question, in line with the construct of coercive control, was that controlling partner behavior would significantly determine physical partner violence during pregnancy and lifetime physical partner violence, consistent with the literature that coercive control is a primary motivator for other forms of IPV (21). The hypothesis for the second research question was that physical violence during pregnancy would be associated with significantly worse self-reported health and significantly greater likelihood of suicide ideation.

\section{MATERIALS AND METHODS}

\section{Data}

The data analyzed in this study are from the 2017 Guyana Women's Health and Life Experiences Survey. The crosssectional survey was a collective effort of several organizations led by the Government of Guyana through the Ministry of Social Protection, the Ministry of Public Health, and the Bureau of Statistics, and supported by the United Nations Entity for Gender Equality and the Empowerment of Women (UN Women), the United Nations Development Programme (UNDP), the Inter-American Development Bank, the United States Agency for International Development (USAID), the University of Guyana, and the Global Women's Institute at the George Washington University. Data are from a nationally representative household survey carried out in 2017. The Guyana Bureau of Statistics calculated the sample size using a standardized multistage sampling procedure with weighting (4). The dataset has 1498 observations and 1360 variables. The total sample size was 1498 women and after dropping never-partnered women from the dataset, the final sample size was 1391 women. The 
study used a structured questionnaire administered by trained interviewers. The questionnaire consisted of a general household questionnaire that could be answered by any adult in the household, and a woman's questionnaire comprised of 12 sections. Eligible women were any female in the household between the ages of 15 and 64 years. If there was more than one eligible woman per household, one woman was randomly selected using a Kish grid. The study team determined that the data did not need to be weighted and so no weighting was done in this secondary data analysis. The full study details and methodologies are reported elsewhere (4).

The questionnaire used was the standard WHO Violence Against Women and Girls prevalence survey adapted for the Guyana setting (4). The questionnaire includes sections on women's general health, reproductive health, children's health and behavior, current or most recent husband/partner, attitudes (on gender and acceptability of IPV), her current/past relationships with a male partner, injuries from physical and/ or sexual violence, impact and coping from physical/sexual violence, and other experiences of non-partner violence.

Dependent variables. The main outcomes for this secondary analysis include physical violence during pregnancy, women's health, and suicide ideation. While the full survey questionnaire included questions on other forms of IPV (including sexual, economic, and emotional violence), measurement of IPV-P was limited to exposure physical violence and therefore the analysis was restricted to only physical partner violence.

Predictors. For the first research question, the predictors associated with physical violence during pregnancy and lifetime physical violence, the main predictor was controlling partner behavior (a binary variable defined as the partner exhibiting at least one of eight controlling behaviors, such as trying to limit the woman's contact with friends, family of birth, etc.). For the second research question, the relationship between physical partner violence during pregnancy and women's health (a categorical variable from $1=$ excellent to $5=$ very poor health) and between physical partner violence during pregnancy and suicide ideation (a binary variable with $0=$ no and 1 = yes), the main predictor was physical violence during pregnancy (a binary variable defined as whether or not the woman experienced physical IPV during pregnancy).

Study covariates. Study covariates included demographic variables as well as other covariates that have been shown in the literature to influence the main dependent variables. Demographic variables included place of residence (hinterland, rural, suburban, and urban), age, total years of education, source of income (no income, income from own work, income from husband/partner, equal share of income from self and husband/ partner, and other), and marital status (married, common-law, regular or visiting male partner, or single). Other covariates included whether the partner wanted children (a binary variable categorized as the partner wanted to wait until later or did not want children versus the partner wanted the woman to become pregnant then), whether the woman chose her current partner (a binary variable categorized as $0=$ the woman chose and/or she and her partner chose and 1 = the partner chose, the partner's family chose, or the woman's family chose), family access (a binary variable categorized as whether or not the woman can easily see or visit family with $0=$ yes and $1=$ no), family support (a binary variable categorized as whether or not the woman reported she could count on members of family for support when she needs help or has a problem, with $0=$ yes and $1=$ no), daily partner alcohol use (a binary variable defined as the partner drinking alcohol at least daily versus not, with $0=$ not drinking alcohol daily and $1=$ drinks alcohol daily) and whether the woman reported being physically beaten as a child $(0=$ no and $1=$ yes $)$.

\section{Data analysis}

Descriptive statistics were calculated, including demographic characteristics stratified by women who reported being pregnant at least once and never experiencing any physical violence, women who reported being pregnant at least once and experienced lifetime physical violence, and women who reported being pregnant and experienced physical violence during pregnancy. Chi-square tests were run to examine differences in proportions of dependent variables (exposure to physical violence) and independent variables.

For the first research question, determinants of experiencing physical partner violence during pregnancy, a preliminary multinomial logistic regression model was fitted to estimate the crude association between controlling partner behavior and women who experience physical violence during pregnancy and those who did not experience violence during pregnancy but did experience lifetime physical violence, with women who were pregnant and never experienced any form of physical partner violence as the reference group. Blocks of variables were then added to the models if the $P$-value was significant at the $<0.05$ level. In Model 2, potential confounding demographic variables were added. In Model 3, other potential confounding covariates were added. The analysis was restricted to physical partner violence because the survey did not ask about other forms of intimate partner violence (e.g., sexual, emotional, or economic) during pregnancy. Crude and adjusted relative risk ratios (RRR and aRRR) are reported.

For the second research question, the relationship between exposure to IPV-P and women's health and suicide ideation, an ordered logistic model was fitted to estimate the crude association between physical violence during pregnancy and overall health. Blocks of demographic variables (Model 2) and other covariates (Model 3 ) were then added if the $P$-value was significant at the $<0.05$ level. Crude and adjusted odds ratios (OR and $\mathrm{aOR}$ ) are reported. To examine the association between IPV-P and suicide ideation, multivariate logistic regression models were fitted to estimate the crude association between IPV-P and suicide ideation. Blocks of demographic variables (Model 2) and other covariates (Model 3) were then added if the $P$-value was significant at the $<0.05$ level. Crude and adjusted odds ratios are reported. All analyses were conducted using Stata/IC 15.1.

\section{Ethics}

The survey upon which this secondary analysis is based was approved by the Guyana Ministry of Public Health Institutional Review Board. Informed consent for the survey was obtained from each participant by each enumerator prior to beginning data collection. All data released for analysis were anonymized 
and all identifying information was removed. Each interview was identified using a unique numerical code to protect anonymity.

\section{RESULTS}

\section{Descriptive data}

The final sample size and prevalence of lifetime IPV, current IPV, and physical violence during pregnancy are presented in Table 1. Among ever-partnered women, $37.81 \%$ of women reported experienced lifetime physical and/or sexual violence and $35 \%$ experienced lifetime physical partner violence. In the last 12 months preceding the survey, $11.07 \%$ of women reported experiencing physical and/or sexual violence and $9 \%$ of women reported experiencing physical partner violence. More than half of women, $57.87 \%$, reported experiencing at least one form of controlling partner behavior. Almost one in ten $(9.2 \%)$ women reported physical violence during pregnancy.

The characteristics of ever-partnered women who have been pregnant stratified by exposure to lifetime physical violence and exposure to physical violence during pregnancy are presented in Table 2.

\section{Physical partner violence and controlling partner behavior}

Table 3 shows the results of a multinomial logistic regression model conducted between women who experienced physical violence during pregnancy and women who experienced lifetime physical partner violence compared to women who have been pregnant but have not experienced any form of physical partner violence with controlling partner behavior. The bivariate associations between both forms of physical violence with age, source of income, and geographical residence were non-significant and so not included in subsequent multivariate models. Total years of schooling and partner choice were no longer significant in the multivariate models. In the final model, controlling partner behavior was associated with a significantly increased likelihood of experiencing lifetime physical

TABLE 1. Prevalence of partner violence among ever partnered women, Guyana Women's Health and Life Experiences Survey, 2017

\begin{tabular}{lcc} 
& Number & Percent \\
Women & & \\
Number of eligible women & 1498 & 100 \\
Number of ever partnered women & 1391 & 92.80 \\
Exposed to IPV (lifetime) & & \\
Physical and/or sexual IPV & 526 & 37.81 \\
Physical IPV & 492 & 35.37 \\
$\quad$ Sexual IPV & 194 & 13.95 \\
Exposed to IPV (in the last 12 months) & & 11.07 \\
$\quad$ Physical and/or sexual IPV & 154 & 9.27 \\
Physical IPV & 129 & 4.03 \\
$\quad$ Sexual IPV & 56 & 9.16 \\
Physically attacked while pregnant & 109 & \\
\hline
\end{tabular}

Source: Prepared by the authors based on the study results. violence (aRRR: 2.71; 95\% CI: 2.01-3.66; $P<0.001)$ and experiencing physical violence during pregnancy (aRRR: 4.07; 95\% CI: $2.31-7.18 ; P<0.001)$. Having increased number of pregnancies, being unmarried, lack of family support, experience of physical violence as a child, and partner alcoholism were all significantly associated with increased risk of physical violence during pregnancy. For lifetime physical violence, having a regular or visiting male partner compared to being married, lack of family support, experience of physical violence as a child, and partner alcoholism were significant risk factors.

\section{Overall health and physical partner violence during pregnancy}

Table 4 shows the result of an ordered logistic regression model conducted between self-reported overall health $(1=$ excellent to $5=$ very poor) and experiencing physical violence during pregnancy. In the final model, experiencing physical violence during pregnancy was associated with a 1.49 increase in the odds of reporting poorer health, where each one unit increase on self-reported health corresponds to poorer health (aOR: $1.49 ; 95 \%$ CI: $1.00-2.24 ; P<0.05$ ). We also see a significant association of self-reported poor overall health with age, total number of pregnancies, lack of family support, and controlling partner behavior.

\section{Suicide ideation and physical partner violence during pregnancy}

Table 5 shows the results of a logistic regression model exploring the association between suicide ideation and experiencing physical violence during pregnancy. In the final model, experiencing physical violence during pregnancy was associated with a 4.07 times increase in the odds of suicide ideation (95\% CI: $2.48-6.76 ; P<0.001$ ). The following variables were also significantly associated with an increase in the odds of suicide ideation in the final logistic regression model: rural and suburban geographic area of residence (compared to urban), lack of family support, lack of partner choice, experience of physical violence as a child, and controlling partner behavior.

\section{DISCUSSION}

The data from this survey are the first nationally representative data available on IPV in Guyana, an under-researched context.

The prevalence of violence during pregnancy in Guyana was high at $9.2 \%$, which is likely to have significant downstream health consequences for these women and their children $(1,2)$ including on measures that we were not able to directly assess in the current study, including risk of miscarriage, premature birth, low birthweight, perinatal death, and reduced healthcare utilization by pregnant women; these outcomes should be included in future research (7-9). Similar to other studies, controlling partner behavior was significantly associated with maternal experience of physical violence during pregnancy $(14,22,23)$. Partner alcohol consumption, experience of physical violence as a child, lack of family support, and self-reported poor health were associated with an increased risk of experiencing physical partner violence during pregnancy, also in line with previous research 
TABLE 2. Proportion of women in each category, stratified by exposure to lifetime physical violence and physical violence during pregnancy, Guyana, 2017

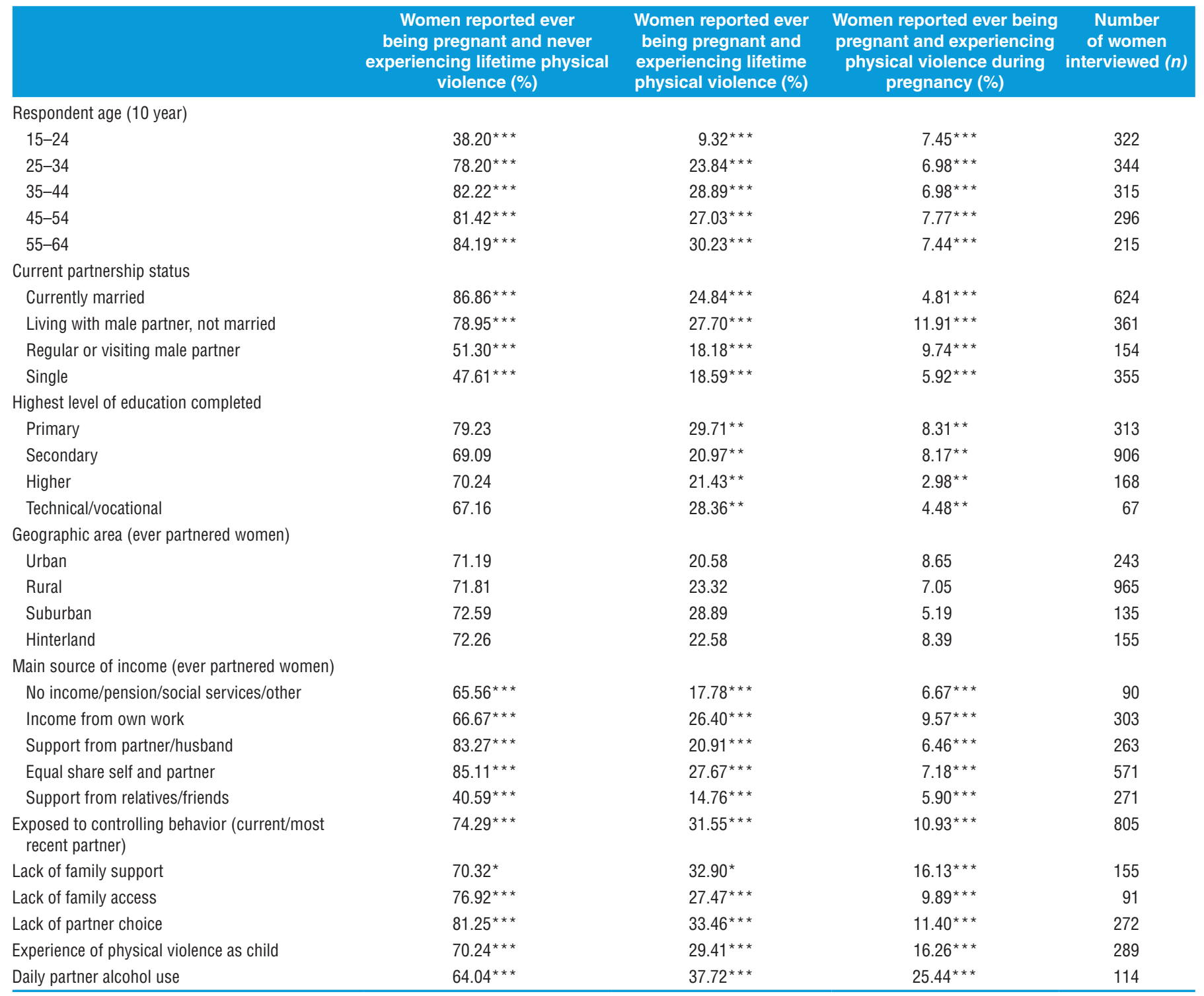

Notes: Significance determined by Pearson's chi-square test.

Parameter estimates statistically different than zero at ${ }^{*} P \leq 0.05,{ }^{* *} P \leq 0.01,{ }^{* * *} P \leq 0.001$

Source: Prepared by the authors based on the study results.

$(6,29,30)$. This study did not find that younger maternal age and low maternal education were significantly associated with higher risk of violence during pregnancy, unlike other studies (6). These findings support the conceptualization of IPV during pregnancy as a pattern of coercive control associated with a range of physical, sexual, emotional, economic, and controlling abusive behaviors, yet the majority of studies, including the survey used for this secondary data analysis, only measure physical violence during pregnancy, which is a narrow and limiting approach.

Women who experience physical violence during pregnancy experience significantly worse self-reported health than those who do not. Women who experience physical partner violence during pregnancy are at significantly greater risk of suicide ideation, supporting previous findings in the literature $(12,31)$. The findings underscore that physical partner violence during pregnancy is a highly distressing experience for women, with serious adverse consequences for their health and well-being.

\section{Limitations}

This study used a cross-sectional design, which makes it difficult to establish the direction of causality and leads to ambiguous temporal precedence and the potential for reverse causality (32). This study used self-reported data. Given the sensitive nature of the questions, including questions on IPV, pregnancy, and sexual behavior and other potentially socially unacceptable behaviors such as abortion, there may have been some response bias influencing the rate of disclosure and/or 
TABLE 3. Risk factors for experiencing physical partner violence, Guyana, 2017

\begin{tabular}{|c|c|c|c|c|c|c|}
\hline & \multicolumn{3}{|c|}{$\begin{array}{c}\text { Women reported ever being pregnant and experiencing } \\
\text { lifetime physical violence }\end{array}$} & \multicolumn{3}{|c|}{$\begin{array}{l}\text { Women reported ever being pregnant and experiencing } \\
\text { physical violence during pregnancy }\end{array}$} \\
\hline & $\operatorname{RRR}(95 \% \mathrm{Cl})$ & $\operatorname{aRRR}(95 \% \mathrm{Cl})$ & $\operatorname{aRRR}(95 \% \mathrm{CI})$ & $\operatorname{RRR}(95 \% \mathrm{Cl})$ & $\operatorname{aRRR}(95 \% \mathrm{Cl})$ & $\operatorname{aRRR}(95 \% \mathrm{Cl})$ \\
\hline Controlling partner behavior & $\begin{array}{c}2.96 \\
(2.25-3.92)^{\star \star *}\end{array}$ & $\begin{array}{c}3.16 \\
(2.35-4.25)^{\star \star \star}\end{array}$ & $\begin{array}{c}2.74 \\
(2.04-3.70)^{\star \star *}\end{array}$ & $\begin{array}{c}4.65 \\
(2.83-7.65)^{\star \star *}\end{array}$ & $\begin{array}{c}4.08 \\
(2.42-6.90)^{\star \star \star}\end{array}$ & $\begin{array}{c}4.14 \\
(2.36-7.29)^{\star * *}\end{array}$ \\
\hline Age & $1.01(1.00-1.02)$ & $1.01(1.00-1.03)$ & & $0.99(0.97-1.00)$ & $0.99(0.96-1.00)$ & \\
\hline Total number of pregnancies & $\begin{array}{c}1.11 \\
(1.06-1.17)^{\star \star \star}\end{array}$ & $\begin{array}{c}1.11 \\
(1.04-1.17)^{\star * *}\end{array}$ & $\begin{array}{c}1.09 \\
(1.03-1.14)^{\star *}\end{array}$ & $\begin{array}{c}1.16 \\
(1.09-1.24)^{\star \star *}\end{array}$ & $\begin{array}{c}1.22 \\
(1.14-1.32)^{\star * *}\end{array}$ & $\begin{array}{c}1.13 \\
(1.05-1.22)^{\star *}\end{array}$ \\
\hline \multicolumn{7}{|l|}{ Marital status } \\
\hline Married & 1 & 1 & 1 & 1 & 1 & 1 \\
\hline $\begin{array}{l}\text { Living with male partner, not } \\
\text { married }\end{array}$ & $\begin{array}{c}1.34 \\
(0.99-1.82)\end{array}$ & $\begin{array}{c}1.28 \\
(0.91-1.81)\end{array}$ & $\begin{array}{c}1.31 \\
(0.94-1.84)\end{array}$ & $\begin{array}{c}2.98 \\
(1.81-4.91)^{\star \star *}\end{array}$ & $\begin{array}{c}2.46 \\
(1.42-4.26)^{\star * *}\end{array}$ & $\begin{array}{c}2.57 \\
(1.48-4.45)^{\star \star *}\end{array}$ \\
\hline Regular or visiting male partner & $\begin{array}{c}1.37 \\
(0.83-2.25)\end{array}$ & $\begin{array}{c}1.48 \\
(0.87-2.53)\end{array}$ & $\begin{array}{c}2.45 \\
(1.26-4.77)^{\star \star}\end{array}$ & $\begin{array}{c}3.79 \\
(1.91-7.52)^{\star \star \star}\end{array}$ & $\begin{array}{c}3.40 \\
(1.60-7.24)^{\star \star *}\end{array}$ & $\begin{array}{c}6.96 \\
(2.93-16.63)^{\star \star *}\end{array}$ \\
\hline Lack of family support & $\begin{array}{c}1.94 \\
(1.30-2.89)^{\star \star \star}\end{array}$ & & $\begin{array}{c}1.83 \\
(1.18-2.84)^{\star *}\end{array}$ & $\begin{array}{c}3.35 \\
(1.99-5.64)^{\star \star \star}\end{array}$ & & $\begin{array}{c}2.63 \\
(1.43-4.83)^{\star \star}\end{array}$ \\
\hline Lack of partner choice & $\begin{array}{c}1.53 \\
(1.13-2.09)^{\star *}\end{array}$ & & $\begin{array}{c}1.36 \\
(0.98-1.90)\end{array}$ & $\begin{array}{c}1.79 \\
(1.12-2.84)^{\star *}\end{array}$ & & $\begin{array}{c}1.50 \\
(0.89-2.53)\end{array}$ \\
\hline $\begin{array}{l}\text { Experience of physical violence } \\
\text { as child }\end{array}$ & $\begin{array}{c}1.65 \\
(1.21-2.27)^{\star \star}\end{array}$ & & $\begin{array}{c}1.45 \\
(1.02-2.05)^{\star}\end{array}$ & $\begin{array}{c}3.92 \\
(2.56-6.04)^{\star \star *}\end{array}$ & & $\begin{array}{c}3.48 \\
(2.14-5.66)^{\star \star}\end{array}$ \\
\hline Daily partner alcohol use & $\begin{array}{c}3.16 \\
(1.95-5.11)^{\star \star \star}\end{array}$ & & $\begin{array}{c}2.53 \\
(1.48-4.30)^{\star \star \star}\end{array}$ & $\begin{array}{c}8.15 \\
(4.67-14.22)^{\star \star \star}\end{array}$ & & $\begin{array}{c}5.37 \\
(2.77-10.40)^{\star \star \star}\end{array}$ \\
\hline Sample size & & 1132 & 1066 & & 1132 & 1066 \\
\hline
\end{tabular}

Notes: RRR, relative risk ratio; aRRR adjusted relative risk ratio.

a Adjusted for sociodemographic factors including overall health, age, total number of pregnancies, marital status, and total years of schooling.

${ }^{b}$ Adjusted for other control variables and significant demographic variables including overall health, total number of pregnancies, and marital status.

Significance determined by $z$-test.

Significance determined by $z$-test.
Parameter estimates statistically different than zero at ${ }^{*} p \leq 0.05,{ }^{* *} p \leq 0.01,{ }^{* * *} p \leq 0.001$.

Source: Prepared by the authors based on the study results.

TABLE 4. Overall health of women experiencing physical partner violence during pregnancy, Guyana, 2017

\begin{tabular}{|c|c|c|c|}
\hline & \multicolumn{3}{|c|}{ Overall health } \\
\hline & Bivariate & Multivariate $1^{\mathrm{a}}$ & Multivariate $2^{\mathrm{b}}$ \\
\hline & $\mathrm{OR}(95 \% \mathrm{Cl})$ & $\mathrm{aOR}(95 \% \mathrm{Cl})$ & $\mathrm{aOR}(95 \% \mathrm{Cl})$ \\
\hline Age & $1.03(1.02-1.06)^{\star * *}$ & $1.02(1.01-1.03)^{\star * *}$ & $1.02(1.02-1.03)^{\star \star \star ~}$ \\
\hline Total number of pregnancies & $1.13(1.09-1.18)^{\star \star *}$ & $1.08(1.04-1.13)^{\star * *}$ & $1.08(1.04-1.13)^{\star \star \star}$ \\
\hline Regular or visiting male partner & $0.83(0.59-1.15)$ & & \\
\hline Single & $1.04(0.82-1.33)$ & & \\
\hline Total years of schooling & $0.93(0.91-0.97)^{\star * *}$ & $0.97(0.94-1.01)$ & \\
\hline \multicolumn{4}{|l|}{ Area (Ref: Urban) } \\
\hline Rural & $0.94(0.73-1.23)$ & & \\
\hline Equal share from own work and partner & $0.65(0.40-1.03)$ & & \\
\hline Support from husband/partner & $0.71(0.46-1.09)$ & & \\
\hline Other & $0.69(0.44-1.10)$ & & \\
\hline Lack of family support & $2.29(1.65-3.16)^{\star \star *}$ & & $1.61(1.11-2.35)^{\star}$ \\
\hline
\end{tabular}


TABLE 4. (Continued)

\begin{tabular}{|c|c|c|c|}
\hline & & Overall health & \\
\hline & Bivariate & Multivariate $1^{\mathrm{a}}$ & Multivariate $2^{b}$ \\
\hline & OR $(95 \% \mathrm{CI})$ & aOR $(95 \% \mathrm{Cl})$ & aOR $(95 \% \mathrm{Cl})$ \\
\hline Lack of family access & $1.70(1.13-2.57)^{\star}$ & & $1.33(0.84-2.12)$ \\
\hline Lack of partner choice & $1.18(0.91-1.52)$ & & \\
\hline Experience of physical violence as child & $1.30(1.01-1.67)^{\star}$ & & $1.20(0.91-1.58)$ \\
\hline Partner alcohol use & $1.51(1.05-2.18)^{\star}$ & & $1.12(0.76-1.68)$ \\
\hline
\end{tabular}

Notes: OR, odds ratio; aOR, adjusted odds ratio.

a Adjusted for sociodemographic factors including age, total number of pregnancies, and total years of schooling.

'Adjusted for other control variables and significant demographic variables including age and total number of pregnancies.

Significance determined by z-test.

Parameter estimates statistically different than zero at ${ }^{*} p \leq 0.05,{ }^{* *} p \leq 0.01,{ }^{* * *} p \leq 0.001$

Source: Prepared by the authors based on the study results.

TABLE 5. Suicide ideation and experiencing physical partner violence during pregnancy, Guyana, 2017

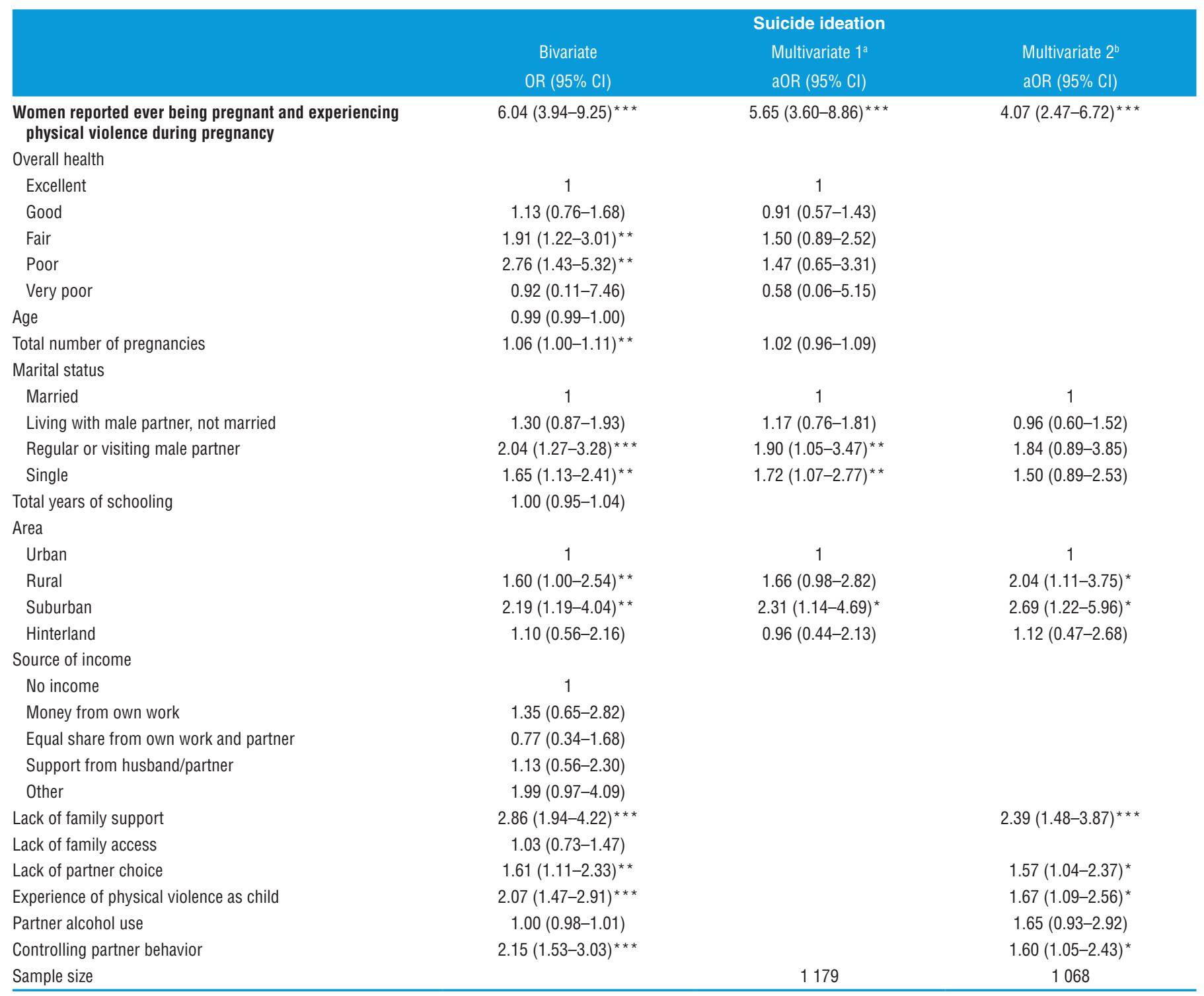

Notes: OR, odds ratio; aOR, adjusted odds ratio.

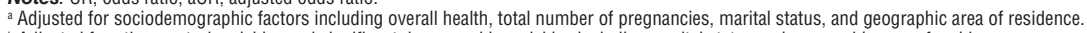

b Adjusted for other control variables and significant demographic variables including marital status and geographic area of residence.

Significance determined by z-test.

Parameter estimates statistically different than zero at ${ }^{*} p \leq 0.05,{ }^{* *} p \leq 0.01,{ }^{* * *} p \leq 0.001$

Source: Prepared by the authors based on the study results. 
recall bias, although the training interviewers received prior to data collection hopefully minimized this. Nonetheless, under-reporting could have weakened the estimated effects (1). Further, the study did not collect complete information on demographic data, in particular, income level; only income source was collected. Therefore, it was not possible to control for income level or rule it out as a potential confounder.

\section{Implications and recommendations}

Future research could use other cross-sectional data, such as from the Demographic and Health Survey, to further examine the relationship between IPV and women's health outcomes in other countries. Ideally, a longitudinal dataset would be identified or constructed to establish the direction of causality for each of the research questions included in this study; using a dataset that has been specifically constructed to examine the pathways between IPV and maternal health will facilitate more sophisticated analyses, greater confidence in the direction of causality, and therefore more targeted and effective programming (1).

\section{Conclusion}

The current study contributes to the literature on the determinants of physical violence during pregnancy and lifetime physical violence, as well as the association between physical violence during pregnancy and maternal health outcomes. The predictors associated with IPV-P included controlling partner behavior, partner alcohol consumption, childhood physical violence, lack of family support, and poor self-reported health. IPV-P was associated with an increased risk of suicide ideation and poor health outcomes. The results can inform programming and policy-making on these significant public health issues.

Given the high rates of IPV and IPV-P in the current sample, greater efforts for IPV prevention and intervention are needed, particularly in the context of the COVID-19 pandemic and increased rates of IPV reported in the LAC region and globally $(33,34)$. IPV screening and treatment should be fully integrated into antenatal care and maternal health programs and services, as well as other service delivery points such as outpatient clinics and mental health services, to identify and treat women at high risk (18). In countries such as Guyana where universal IPV and IPV-P screening guidelines already exist, operations research to inform effective implementation and pinpoint gaps in coverage is needed. Cost-effectiveness studies of IPV-P screening, prevention, and response interventions are lacking to inform policymakers. Healthcare providers and social service workers may need additional training and sensitization to identify and respond to IPV (35), including adequate psychological support and referrals to legal services (6) to prevent and address the IPV and the physical and mental health toll it exacts on a significant proportion of pregnant women.

Author contributions. LM and MU-C both participated in the study design. LM carried out the statistical analysis for this paper and drafted the manuscript. MU-C helped draft and review the manuscript. Both authors read and approved the final manuscript version.

Acknowledgments. This secondary data analysis would not have been possible without the participation of the courageous women who took part in the survey. We also thank the enumerators, supervisors, monitors, and other research team members from the Guyana Bureau of Statistics and the University of Guyana. The government ministers who approved and supported the survey include the Honorable Amna Ally, Minister of Social Protection; the Honorable Volda Lawrence, Minister of Public Health; and the Honorable Khemraj Ramjattan, Third Vice President and Minister of Public Security. Special thanks go to the Global Women's Institute of the George Washington University. Appreciation also goes to the donor and development partner agencies' staff from UN Women, UNDP, and the Inter-American Development Bank. We thank Angela Bourassa for her assistance with revisions.

\section{Conflicts of interest. None declared.}

Financial support. The funders had a coordination role in the study but not specifically in the study design, data collection, data analysis, data interpretation, writing of the report, or decision to publish these results. The corresponding author had full access to all the data in the study and had final responsibility for the decision to submit for publication.

Disclaimer. Authors hold sole responsibility for the views expressed in the manuscript, which may not necessarily reflect the opinion or policy of the RPSP/PAJPH and/or the Pan American Health Organization (PAHO).

\section{REFERENCES}

1. Bott S, Guedes A, Goodwin M, Mendoza JA. Violence Against Women in Latin America and the Caribbean: A comparative analysis of population-based data from 12 countries. Pan American Health Organization: Washington, D.C.; 2012.

2. Rico E, Fenn B, Abramsky T, Watts C. Associations between maternal experiences of intimate partner violence and child nutrition and mortality: findings from Demographic and Health Surveys in Egypt, Honduras, Kenya, Malawi and Rwanda. J Epidemiol Community Health [Internet]. 2011 Apr 1 [cited 2019 Jan 26];65(4):360-7. Available from: http://www.ncbi.nlm.nih.gov/pubmed/20841374

3. Parekh K, Russ S, Amsalem D, Rambaran N, Langston S, Wright S. Prevalence of intimate partner violence in patients presenting with traumatic injuries to a Guyanese emergency department. Int J Emerg Med [Internet]. 2012 Dec;5(1):1-5. Available from: https:/ / www.ncbi.nlm.nih.gov/pubmed/22643023

4. Contreras-Urbina M, Bourassa A, Myers R, Ovince J, Rodney R, Bobbili S. Guyana Women's Health and Life Experiences Survey Report [Internet]. Government of Guyana, UNDP, USAID, IDB, UN Women, University of Guyana, and The Global Women's Institute, The George Washington University. 2019. Available from: https:// caribbean.unwomen.org/en/materials/publications/2019/11/ guyana-womens-health-and-life-experiences-survey-report

5. World Health Organization. Intimate partner violence during pregnancy [Internet]. Geneva: WHO; 2011. Available from: 
https://www.who.int/reproductivehealth/publications/violence/ rhr_11_35/en/.

6. Han A, Stewart DE. Maternal and fetal outcomes of intimate partner violence associated with pregnancy in the Latin American and Caribbean region. Int J Gynecol Obstet. 2014;124(1):6-11.

7. Musa A, Chojenta C, Geleto A, Loxton D. The associations between intimate partner violence and maternal health care service utilization: A systematic review and meta-analysis. BMC Womens Health [Internet]. 2019 Feb 26 [cited 2020 Jul 28];19(1). Available from: https://pubmed.ncbi.nlm.nih.gov/30808353/.

8. Pastor-Moreno G, Ruiz-Pérez I, Henares-Montiel J, Escribà-Agüir V, Higueras-Callejón C, Ricci-Cabello I. Intimate partner violence and perinatal health: a systematic review [Internet]. BJOG. 2020;127(5):537-47 [cited 2020 Jul 28]. Available from: https:// pubmed.ncbi.nlm.nih.gov/31912613/.

9. Pastor-Moreno G, Ruiz-Pérez I, Henares-Montiel J, Petrova D. Intimate partner violence during pregnancy and risk of fetal and neonatal death: a meta-analysis with socioeconomic context indicators [Internet]. Am J Obstet Gynecol. 2020;222(2):123-33.e5 [cited $2020 \mathrm{Jul}$ 28]. Available from: https://pubmed.ncbi.nlm.nih. gov/31394067/.

10. Kita S, Chan KL, Tobe H, Hayashi M, Umeshita K, Matsunaga M, et al. A Follow-Up Study on the Continuity and Spillover Effects of Intimate Partner Violence During Pregnancy on Postnatal Child Abuse. J Interpers Violence [Internet]. 2019 Jan 10 [cited 2020 Jul 30];886260518821460. Available from: http://www.ncbi.nlm.nih. gov/pubmed/30628550

11. Hatcher AM, Romito P, Odero M, Bukusi EA, Onono M, Turan JM. Social context and drivers of intimate partner violence in rural Kenya: implications for the health of pregnant women. Cult Health Sex. 2013;15(4):404-19.

12. Alhusen JL, Frohman N, Purcell G. Intimate partner violence and suicidal ideation in pregnant women. Arch Womens Ment Health. 2015 Aug 25;18(4):573-8.

13. Shamu S, Zarowsky C, Roelens K, Temmerman M, Abrahams N. High-frequency intimate partner violence during pregnancy, postnatal depression and suicidal tendencies in Harare, Zimbabwe. Gen Hosp Psychiatry. 2016 Jan 1;38:109-14.

14. Halim N, Beard J, Mesic A, Patel A, Henderson D, Hibberd P. Intimate partner violence during pregnancy and perinatal mental disorders in low and lower middle income countries: A systematic review of literature, 1990-2017 [Internet]. Clin Psychol Rev. 2018;66:117-35 [cited 2020 Jul 28]. Available from: https://pubmed. ncbi.nlm.nih.gov/29198412/.

15. Nesari M, Olson JK, Vandermeer B, Slater L, Olson DM. Does a maternal history of abuse before pregnancy affect pregnancy outcomes? A systematic review with meta-analysis. BMC Pregnancy Childbirth. 2018;18(1):404 [Internet]. [cited 2020 Jul 28]. Available from: https://pubmed.ncbi.nlm.nih.gov/30326858/.

16. Berhe AK, Kassa GM, Fekadu GA, Muche AA. Prevalence of hypertensive disorders of pregnancy in Ethiopia: A systemic review and meta-analysis. BMC Pregnancy Childbirth. 2018 Jan 18;18(1).

17. García-Moreno C Ellsberg M et al. JHA. WHO Multi-Country Study on Women's Health and Domestic Violence against Women: initial results on prevalence, health outcomes and women's responses. Geneva: World Health Organization; 2005.

18. Shamu S, Abrahams N, Temmerman M, Musekiwa A, Zarowsky C, Vitzthum V. A Systematic Review of African Studies on Intimate Partner Violence against Pregnant Women: Prevalence and Risk Factors (Intimate Partner Violence in Pregnancy in Africa). PLoS One. 2011;6(3):e17591.

19. Devries KM, Kishor S, Johnson H, Stöckl H, Bacchus LJ, GarciaMoreno C, et al. Intimate partner violence during pregnancy: analysis of prevalence data from 19 countries. Reprod Health Matters. 2010;18(36):158-70.

20. Hindin MJ Ansara DL KS. Intimate Partner Violence among Couples in 10 DHS Countries: Predictors and Health Outcomes. Calverton: Macro International; 2008.

21. Stark E. Commentary on Johnson's "Conflict and Control: Gender Symmetry and Asymmetry in Domestic Violence." Violence Against
Women [Internet]. 2006 [cited 2020 Jan 31];12(11):1019-25. Available from: https:/ / doi.org/10.1177/1077801206293329

22. Charles P, Perreira KM. Intimate partner violence during pregnancy and 1-year post-partum. J Fam Violence. 2007 Oct 5;22(7):609-19.

23. Ludermir AB, Lewis G, Valongueiro SA, De Araújo TVB, Araya $R$. Violence against women by their intimate partner during pregnancy and postnatal depression: A prospective cohort study. Lancet. 2010 Sep 11;376(9744):903-10.

24. Tanha M, Beck CJA, Figueredo AJ, Raghavan C. Sex Differences in Intimate Partner Violence and the Use of Coercive Control as a Motivational Factor for Intimate Partner Violence. J Interpers Violence [Internet]. 2010;25(10):1836-54. [cited 2020 Jan 31]. Available from: http:/ /jiv.sagepub.com

25. Ministry of Public Health Bureau of Statistics (Guyana). 2012 Population \& Housing Census: final report [Internet]. Georgetown: $\mathrm{MOH} ;$ 2012. Available from: https://statisticsguyana.gov.gy/ publications/.

26. Rose EM, Rajasingam D, Derkenne RC, Mitchell V, Ramlall AA. Reproductive health knowledge, attitudes and practices of adolescents attending an obstetric unit in Georgetown, Guyana. J Fam Plann Reprod Health Care. 2016;42(2):116-8. [cited 2020 Jan 5] Available from: https://srh.bmj.com/content/42/2/116.

27. Mitchell V, Parekh KP, Russ S, Forget NP, Wright SW. Personal experiences and attitudes towards intimate partner violence in healthcare providers in Guyana. International Health. 2013;5(4):273-9. [cited 2020 Jan 5] Available from: https://academic.oup.com/inthealth/ article-abstract $/ 5 / 4 / 273 / 707478$

28. Heise LL. Violence against women: an integrated, ecological framework. Violence Against Women. 1998;4(3):262-90. [cited 2020 Feb 28] Available from: http://journals.sagepub.com/ doi $/ 10.1177 / 1077801298004003002$

29. Hill A, Pallitto C, McCleary-Sills J, Garcia-Moreno C. A systematic review and meta-analysis of intimate partner violence during pregnancy and selected birth outcomes. Int J Gynecol Obstet [Internet] 2016 Jun 1 [cited 2020 Feb 14];133(3):269-76. Available from: http:/ / doi.wiley.com/10.1016/j.ijgo.2015.10.023

30. Sigalla GN, Rasch V, Gammeltoft T, Meyrowitsch DW, Rogathi J, Manongi $\mathrm{R}$, et al. Social support and intimate partner violence during pregnancy among women attending antenatal care in Moshi Municipality, Northern Tanzania. BMC Public Health [Internet]. 2017 Dec 9 [cited 2020 Feb 14];17(1):240. Available from: http:/ / bmcpublichealth.biomedcentral.com/articles/10.1186/ s12889-017-4157-3

31. Audi CAF, Segall-Corrça AM, Santiago SM, Pérez-Escamilla R. Adverse health events associated with domestic violence during pregnancy among Brazilian women. Midwifery. 2012 Aug 1;28(4): 416-21.

32. Setia M. Methodology series module 3: Cross-sectional studies. Indian J Dermatol. 2016;61(3):261-4.

33. Bartels-Bland E. COVID-19 Could Worsen Gender Inequality in Latin America and the Caribbean [Internet]. 2020 [cited 2020 Jul 30]. Available from: https://www.worldbank.org/en/news/feature/2020/05/15/ covid-19-could-worsen-gender-inequality-in-latin-america-and-the -caribbean

34. Bradbury-Jones C, Isham L. The pandemic paradox: The consequences of COVID-19 on domestic violence. J Clin Nurs [Internet]. 2020 Jul 22 [cited 2020 Jul 30];29(13-14):2047-9. Available from: https://onlinelibrary.wiley.com/doi/abs/10.1111/ jocn. 15296

35. Owaka IO, Nyanchoka MK, Atieli HE. Intimate partner violence in pregnancy among antenatal attendees at health facilities in West Pokot county, Kenya. Pan Afr Med J. 2017;28.

Manuscript submitted on 20 May 2020. Revised version accepted for publication on 10 August 2020. 


\section{Análisis de los determinantes y las consecuencias de la violencia de pareja durante el embarazo en mujeres de Guyana: resultados de una encuesta domiciliaria transversal representativa a nivel nacional}

RESUMEN Objetivo. Determinar los factores predictivos relacionados con la violencia física durante el embarazo y determinar la relación entre la exposición a la violencia de pareja durante el embarazo y la ideación suicida y la salud de las mujeres en Guyana.

Métodos. Se realizó un análisis secundario de los datos obtenidos de una encuesta domiciliaria transversal. Se adaptaron modelos multifactoriales de regresión logística a los datos para calcular la asociación entre la violencia física durante embarazo, comportamiento controlador de la pareja y otros factores predictivos. Se emplearon modelos ordenados de regresión logística para calcular la asociación entre la violencia física durante el embarazo y la salud de la mujer, y la violencia de pareja a lo largo de la vida y la salud en general. Se aplicaron modelos de regresión logística para calcular la asociación entre la violencia física durante el embarazo y la violencia de pareja a lo largo de la vida y la ideación suicida y la salud en general.

Resultados. La prevalencia de la violencia física o sexual infligida por la pareja a lo largo de la vida fue 38,8\%, la violencia física o sexual infligida por la pareja en la actualidad fue 11,1\% y la violencia durante el embarazo fue $9,2 \%$. El comportamiento controlador de la pareja mostró una asociación positiva y significativa con una experiencia materna de violencia física durante el embarazo. Sufrir violencia física durante el embarazo, aunque no a lo largo de la vida, se asoció significativamente con mayores probabilidades de un estado de salud general deficiente. Tanto la violencia física durante el embarazo como la violencia física a lo largo de la vida se asociaron significativamente con mayores probabilidades de ideación suicida.

Conclusiones. La prevalencia de la violencia durante el embarazo en Guyana es alta y está relacionada con consecuencias adversas en materia de salud. Estos resultados ponen de manifiesto la necesidad de prevenir la violencia de pareja y de integrar su detección y tratamiento en la atención prenatal, los servicios de salud reproductiva y los programas y servicios de salud maternoinfantil para detectar y tratar a las mujeres en riesgo.

Palabras clave Violencia de pareja; embarazo; violencia doméstica; abuso físico; salud mental; Guyana. 


\section{Conhecendo os determinantes e os desfechos da violência por parceiro íntimo contra mulheres na gravidez na Guiana: resultados de uma pesquisa transversal domiciliar com representatividade nacional}

RESUMO Objetivo. Determinar as variáveis preditivas associadas à violência física contra mulheres na gravidez e avaliar a relação entre exposição à violência por parceiro íntimo na gravidez e saúde e ideação suicida em mulheres na Guiana.

Métodos. Foi realizada uma análise dos dados secundários de uma pesquisa transversal domiciliar. Modelos de regressão logística multivariada foram ajustados ao conjunto de dados para estimar a associação entre violência física na gravidez, controlando-se o efeito do comportamento do parceiro e outras variáveis preditivas. Modelos de regressão logística ordinal foram ajustados para estimar a associação entre violência física na gravidez e saúde das mulheres e violência física por parceiro íntimo ao longo da vida e saúde geral. Modelos de regressão logística foram ajustados para estimar a associação entre violência física na gravidez e violência física por parceiro íntimo ao longo da vida e saúde geral e ideação suicida.

Resultados. Observou-se uma prevalência de 38,8\% de violência física/sexual por parceiro íntimo ao longo da vida, $11,1 \%$ de violência física/sexual por parceiro íntimo no momento presente e 9,2\% de violência física/ sexual na gravidez. Controlando-se o efeito do comportamento do parceiro, verificou-se uma associação positiva significativa com experiência materna de violência física na gravidez. Sofrer violência física por parceiro íntimo na gravidez, mas não violência física por parceiro íntimo ao longo da vida, foi associado a uma chance significativamente maior de saúde geral ruim. Verificou-se uma associação significativa entre violência física na gravidez e violência física ao longo da vida e uma maior chance de ideação suicida.

Conclusões. A prevalência da violência contra mulheres na gravidez na Guiana é alta e está associada a desfechos de saúde adversos. Esses resultados apontam para a necessidade de prevenir a violência por parceiro íntimo e integrar a avaliação da violência por parceiro íntimo e o tratamento das mulheres aos serviços de assistência pré-natal e de saúde reprodutiva e programas e serviços de saúde materno-infantil para identificar e tratar as mulheres em risco.

Palavras-chave Violência por parceiro íntimo; gravidez; violência doméstica; abuso físico; saúde mental; Guiana. 